\title{
RATED STRESS STATE OF FUNCTIONAL SURFACES BY X-RAY DIFFRACTOMETRIC METHODS
}

\author{
Peter Kurňava, Dana Stančeková, Tomas Nosák, Marian Jurky
}

S u m m a r y

This work deals with investigation of residual stresses during by non-destructive methods turning Workpiece material, which was used in experiments was 19830 steel, which is used for rolling bearing rings. Residual stress were observed in the application of various cutting parameters by nondestructive methods.

Keywords: x-ray diffractometric method, stress, bearings

Pomiar naprężenia własnego w warstwie wierzchniej metodami dyfraktometrii rentgenowskiej

$$
\text { Streszczenie }
$$

W pracy prowadzono badania naprężeń własnych w warstwie wierzchniej w procesie toczenia przy zastosowaniu metod nieniszczących - metody dyfrakcji rentgenowskiej. W badaniach stosowano stal 19830 do wytwarzania pierścieni łożysk tocznych. Pomiar wartości naprężenia prowadzono na powierzchni obrobionej przy stosowaniu różnych wartości parametrów skrawania.

Słowa kluczowe: metoda dyfraktometrii rentgenowskiej, naprężenia, łożyska toczne

\section{Introduction}

With modern analytical and computational techniques it is usually possible to assess whether there are tensions in parts. It is not sufficient for a reliable prognosis of the properties of the component. If during the performance of functions in the process there was an unexpected failure of components, in many cases this was due to the presence of residual stresses which can significantly shorten the life of components. The compressed nature of stress may be beneficial, for example, in some ways for finishes balling of cyclically loaded components. But mostly the negative effects of residual stress, especially the tensile nature, can create cracks, stress corrosion, reduce fatigue resistance. There are many mechanical, physical, and indirect methods to determine

Address: P. KURŇAVA, Eng., D. STANČEKOVÁ, assoc. prof., PhD. Eng., T. NOSÁK, Eng., M. JURKY, Eng., Department of Machining and Manufacturing Technology, Faculty of Mechanical Engineering, University of Žilina, Univerzitná 8215/1, 01026 Žilina, Slovakia, peter.kurnava@fstroj.uniza.sk 
residual stresses. But now non-destructive methods become more popular, because the tested component is fully functional, undamaged and ready for immediate inclusion in the manufacturing process. The non-destructive technology is for example X-ray diffractometry. These devices can capture not only the surface but also inside the studied samples and map the nature of the tensions that are in it and exactly where they are located. Following to the results of examinations, the tensions can be removed by heat treatment, annealing or shot blasting $[1 \div 8]$.

\section{Aim of work}

The work process is the issue of residual stresses of the Class 19 tool steel for cold forming. The measurements were performed using a device to measure residual stresses iXRD Combo. The work was be divided into parts, which extend theoretical - practical possibilities, skills and knowledge of the solution of residual stresses after machining of materials by turning and grinding.

- Monitoring of residual stresses beneath the surface of the machining tools with defined and undefined geometry of the cutting wedge.

- Monitoring of residual stresses below the surface by grinding sharp and blunt grinding wheel.

- Design of basic research, application of non-destructive detection methods.

The performed experiments and evaluated to identify and intensify the process of turning aside to dry materials characterized by high hardness and strength will significantly expand the current knowledge of the field.

\section{Methods of measuring residual stress}

The machined surface is micro inequal. Force effects of the tool and thin surface layer below the machined surface deforms. As a result of deformation and heating of the formed surface layer in this layer the stresses and physical mechanical properties were measured. All these factors affect the functional properties of machined parts, and the quality of machined surface is constantly monitored and evaluated. Status and quality of the surface layer are very important aspects, especially for dynamically loaded components, which are beginning to violate a rule from the surface [7].

Residual stress is one of the manifestations of the machining technology. The production process remains in parts and structures and operates continuously without the external load. Its action significantly affects the functionality of the machined surfaces [8]. 
Stress may be:

- tensile - reduces lifetime,

- compressive - increases durability and reduces fatigue.

In clarifying the specific technological causes of residual stresses, the action of the cutting wedge, and in particular the deformation processes in the cutting zone, according to Fig. 1. must be taken into account [1].

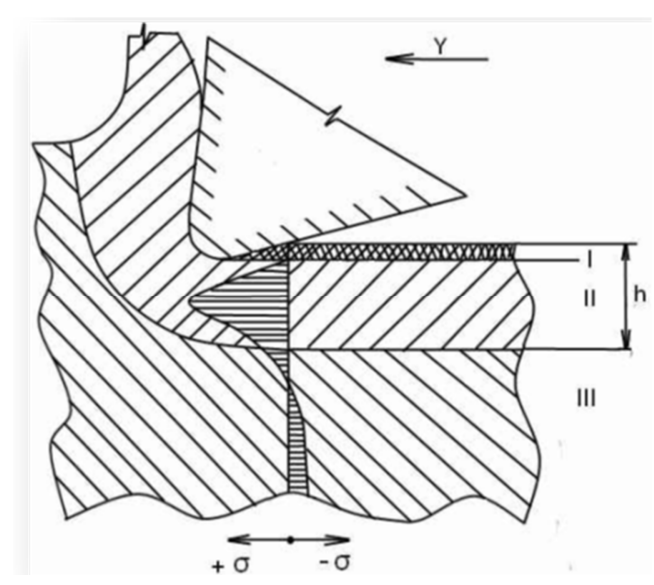

Fig. 1. Diagram of residual stresses in the surface layer under the influence of plastic deformation [1]. I - area of compressive stress induced by friction wedge cutting back on work surface, II - the area of tensile strain introduced by pressing the plastic material, III - unaffected area, such as voltage compensation, I and II

There are many ways for the methods classification.

- depending on the extent to which the integrity of the body under examination:

- destructive - there is a complete deterioration of the body,

- partly destructive - there is only a partial impairment of the body not having an impact on its function and reliability, or you can remove the impairment,

- nondestructive [8].

Between the nondestructive methods for the detection of residual stresses we include diffraction methods for example, $x$-ray diffraction.

Diffraction analysis of residual stresses is one of the most promising methods, although not the easiest in terms of experimental design and 
interpretation of measurement results. The principle is to determine the lattice distortion and converting the stress to the linear theory of elasticity [4].

\section{Experiments}

Cultivated material, used to measure residual stresses was the steel 19830 BÖHLER S 600. 5 thorns (Fig. 2.) served as rolling bearing rings.

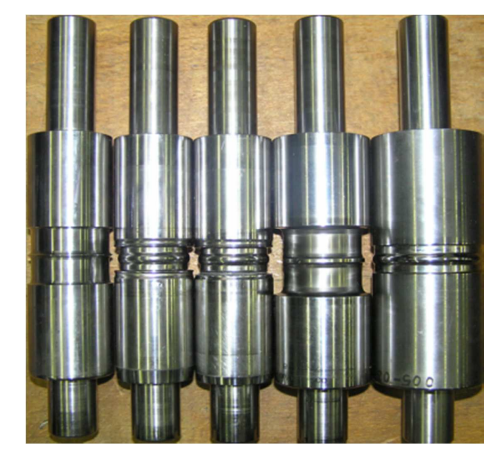

Fig. 2. Thorns on rolling bearing rings

Turning operation was performed on the machine Mazak Nexus 100-II (Fig. 3). Its main advantage is the extreme versatility and productivity, it includes 12-digit turret.

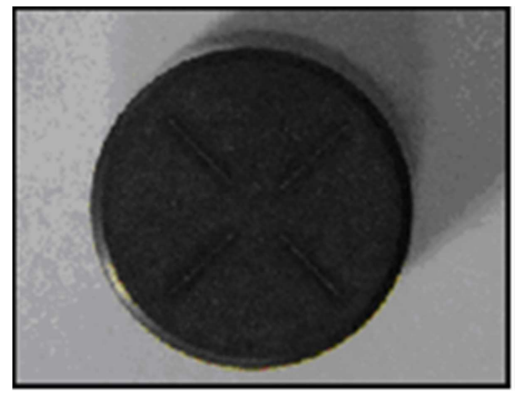

Fig. 3. Circular plate SECO RNMN. 060300 S-type CNB300

The individual operations used different cutting plates. In the roughing circular plate SECO RNMN CNB300 060300 S-type (Fig. 4) was used. 
Cutting conditions for roughing operations:

$$
\begin{gathered}
v_{c}=100 \mathrm{~m} \cdot \min ^{-1}, \quad v_{c}=150 \mathrm{~m} \cdot \mathrm{min}^{-1}, \quad v_{c}=200 \mathrm{~m} \cdot \mathrm{min}^{-1}, \\
f=0.1 \mathrm{~mm}, \quad a_{p}=0.5 \mathrm{~mm}
\end{gathered}
$$

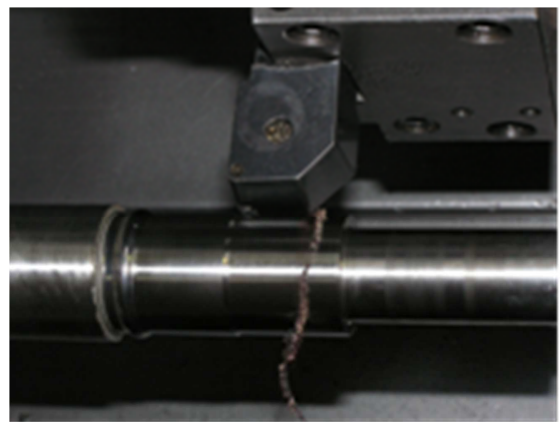

Fig. 4. Roughing with a circular plate of KNB

For the finishing operation cylindrical plate SUMITOMO ELECTRIC type BNC 200 (Fig. 5 and 6) was used.

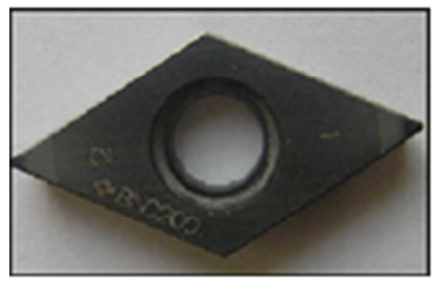

Fig. 5.SUMITOMO ELECTRIC type BNC 200

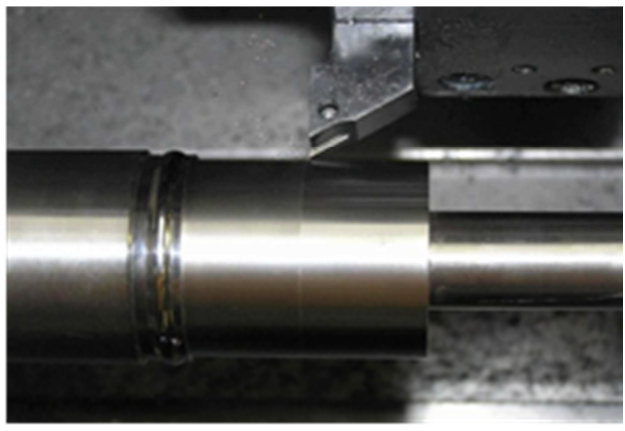

Fig. 6. Finishing with cylindrical plate

Cutting conditions for finishing operations:

$$
\begin{gathered}
v_{c}=100 \mathrm{~m} \cdot \min ^{-1}, \quad v_{c}=150 \mathrm{~m} \cdot \min ^{-1}, \quad v_{c}=200 \mathrm{~m} \cdot \mathrm{min}^{-1}, \\
f=0.05 \mathrm{~mm}, \quad a_{p}=0.1 \mathrm{~mm}
\end{gathered}
$$


Precise machining gradually pushes the technological process of grinding, because by precise turning we can finish machining with such precision and quality that corresponds to the grinded surface. For comparison, we applied the grinded surface quality for those workpieces. The application ran on the sander TOS-HOSTIVAR (Fig. 7). For the experiment we used the blunt and sharp grinding wheel, with three different speeds of rotation of the workpiece. The disc rotated in all cases at constant speed $20000 \mathrm{~m} \cdot \mathrm{s}^{-1}$, and the workpiece was rotated at first - $38 \mathrm{~min}^{-1}$, then $95 \mathrm{~min}^{-1}$ and finally $255 \mathrm{~min}^{-1}$. During grinding and cutting the fluid emulsion $\mathrm{H}$ was applied (2\%).

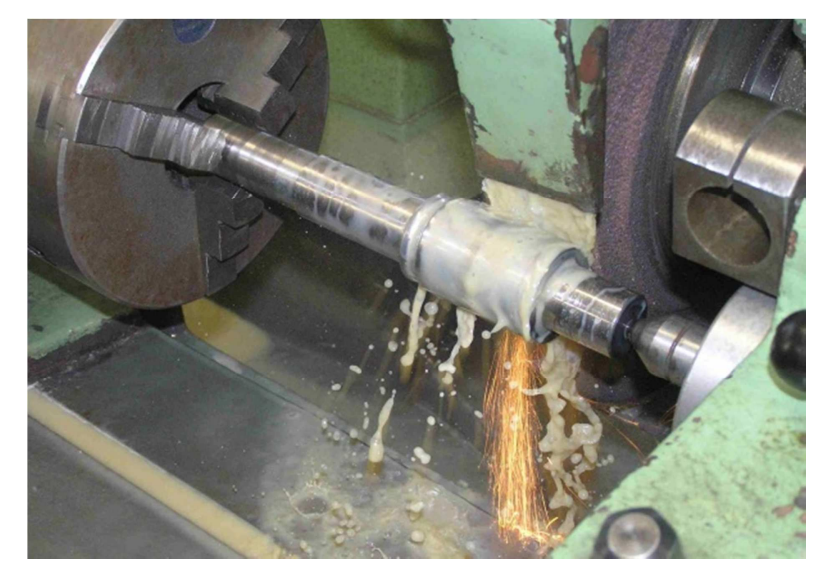

Fig. 7. Sander TOS - HOSTIVǍ̌

One of the main points of the project is to buy a portable nondestructive measurement system for measuring residual stresses XRD (Fig. 8) at the Department of Machining and Manufacturing Technology. Initial experimental measurement, and validation studies on this machine were made in the city of Krakow, the Institute of Nonferrous Metals in Gliwice, Division of Light Metals. iXRD combines versatility, suitability and safety of a fully enclosed housing. Easily transforms from a laboratory system to a portable system in several minutes. iXRD is ideal for customers who need a stable laboratory system, but 


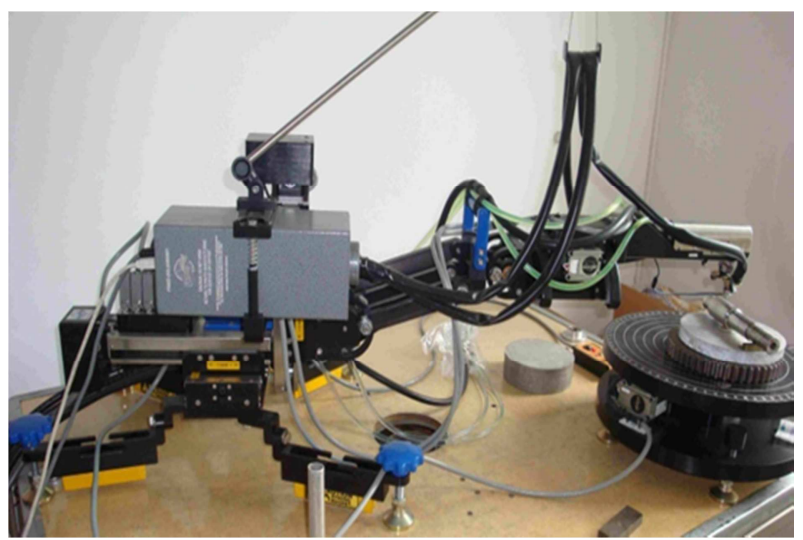

Fig. 8. Measurement system for residual stresses iXRD

also need to be able to work outside, if required. iXRD is available with standard or wide protective cover for large parts, a flexible goniometer, stand off-road and laboratory equipment for mapping of residual stresses.

\section{The measurement procedure}

To measure the residual stresses measurements began by placing the parts into pad measuring system. A detector arm was focused onto unit area (Fig. 9). Stresses were measured in the axial and radial directions. After preparing the parts began to emit X-rays. The device measured the stress to a depth of $12 \mu \mathrm{m}$ in the range of angles around $123-171^{\circ}$. Then the computer was depicted with graphs, which calculated the residual values for shear and residual stresses. These were processed into tables (see Appendix) and these graphs were created.

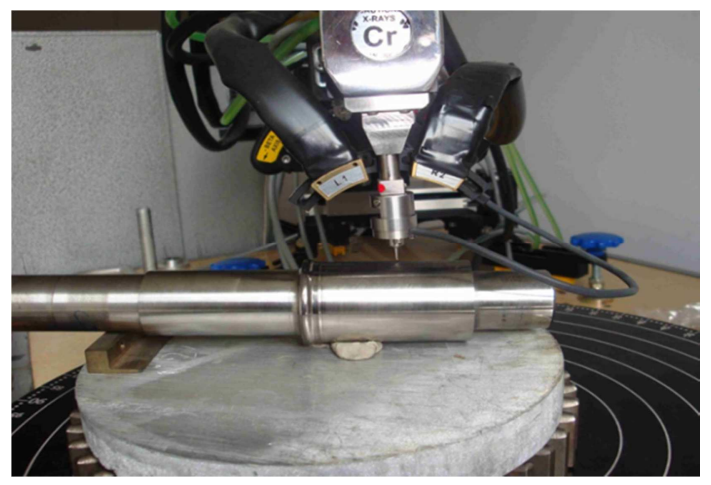

Fig. 9. Focusing the machine on component 


\section{Evaluation of stresses in the thorns}

\section{Turning Roughing Operation}

When using a cutting speed of $v_{c}=100 \mathrm{~m} \cdot \min ^{-1}$ there were measured axially compressed nature of the residual stress, whose value has hovered around -360 MPa, radial residual stress in the application of the same cutting speed showed -175 MPa (Fig. 10). With increasing cutting speed there was a reduction of residual stresses in the axial and radial direction. The value of $v_{c}=150 \mathrm{~m} \cdot \mathrm{min}^{-1}$ to reduce tension in the axial direction was compared to $v_{c}=100 \mathrm{~m} \cdot \min ^{-1}$ by $40 \%$, in the axial direction decreased by $30 \%$. When using $v_{c}=200 \mathrm{~m} \cdot \mathrm{min}^{-1}$ tension in the axial direction decreased to the values of $v_{c}=100 \mathrm{~m} \cdot \mathrm{min}^{-1}$ by $50 \%$, in the radial direction changed by $250 \%$.

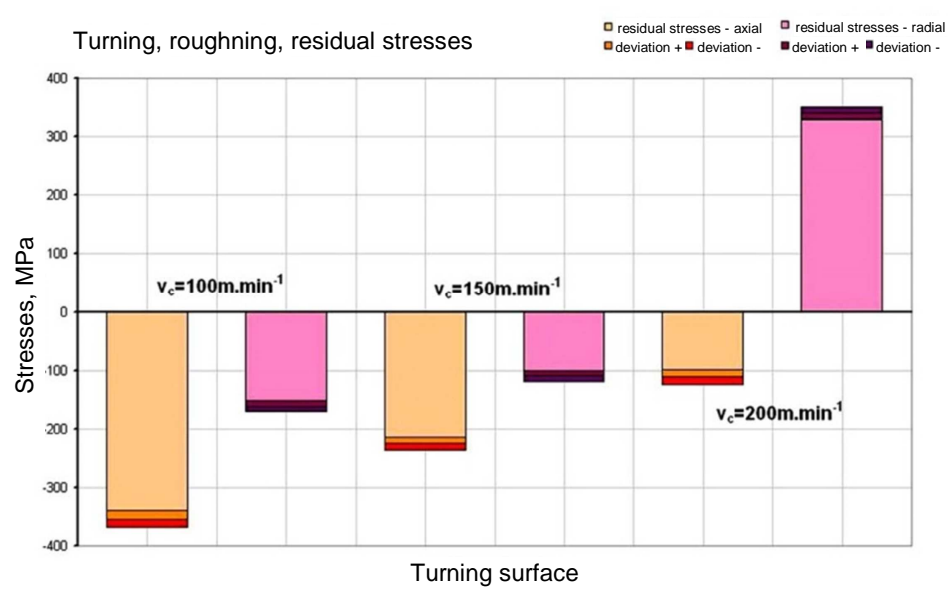

Fig. 10. Diagram of residual stresses in rough turning 


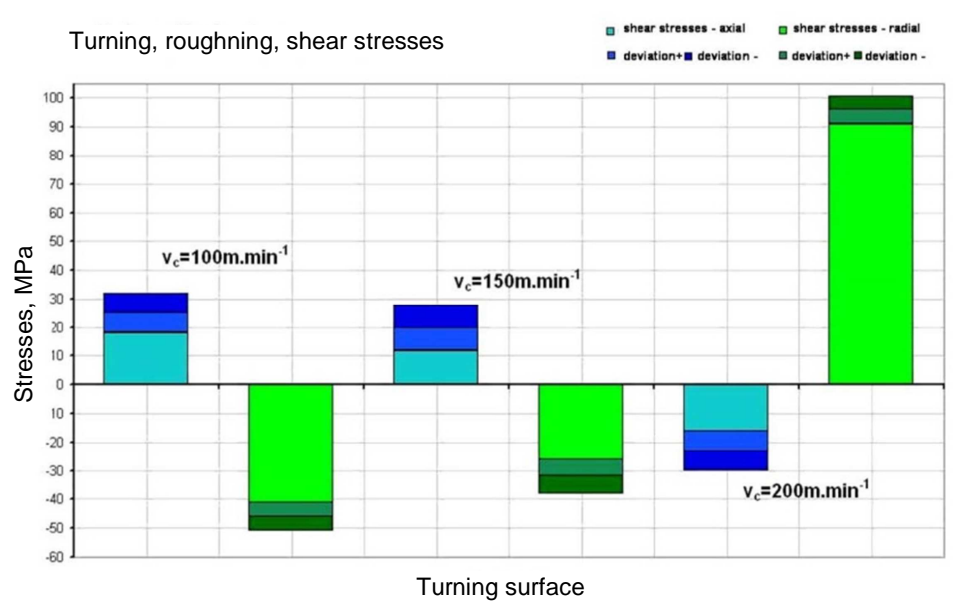

Fig. 11. Diagram of shear stress in rough turning

When using a cutting speed of $v_{c}=100 \mathrm{~m} \cdot \min ^{-1}$ there were measured axial tensile shear stresses of value around $26 \mathrm{MPa}$, radial shear stresses for the same cutting speed showed a value -46 MPa. With increasing cutting speed there was a reduction of shear stress in the axial and radial direction (Fig. 11). The value of $v_{c}=150 \mathrm{~m} \cdot \mathrm{min}^{-1}$, the tensile stress decreased in the axial direction compared to $v_{c}=100 \mathrm{~m} \cdot \mathrm{min}^{-1}$ by $20 \%$ in the radial direction, the compressive stress decreased by $30 \%$. When using $v_{c}=200 \mathrm{~m} \cdot \mathrm{min}^{-1}$ the tensile stress in the axial direction changed by $200 \%$ and the change occurred in the radial direction, where the pressure changed in tensile stress by $300 \%$.

\section{Turning operation finishing}

When using a cutting speed of $v_{c}=100 \mathrm{~m} \cdot \mathrm{min}^{-1}$ there were measured the axial tensions, which values correspond to the voltage $850 \mathrm{MPa}$. Radial residual stress for the same cutting speed showed a value $580 \mathrm{MPa}$. The value $v_{c}=150$ $\mathrm{m} \cdot \mathrm{min}^{-1}$ the tension in the axial direction increased compared to $v_{c}=100$ $\mathrm{m} \cdot \min ^{-1}$ by $2 \%$, in the radial direction increased by $20 \%$. When using $v_{c}=200$ $\mathrm{m} \cdot \mathrm{min}^{-1}$ tension increased in the axial direction to the values of $v_{c}=100$ $\mathrm{m} \cdot \mathrm{min}^{-1}$ by $250 \%$, in the radial direction of the residual stress increased by $25 \%$ (Fig. 12). 


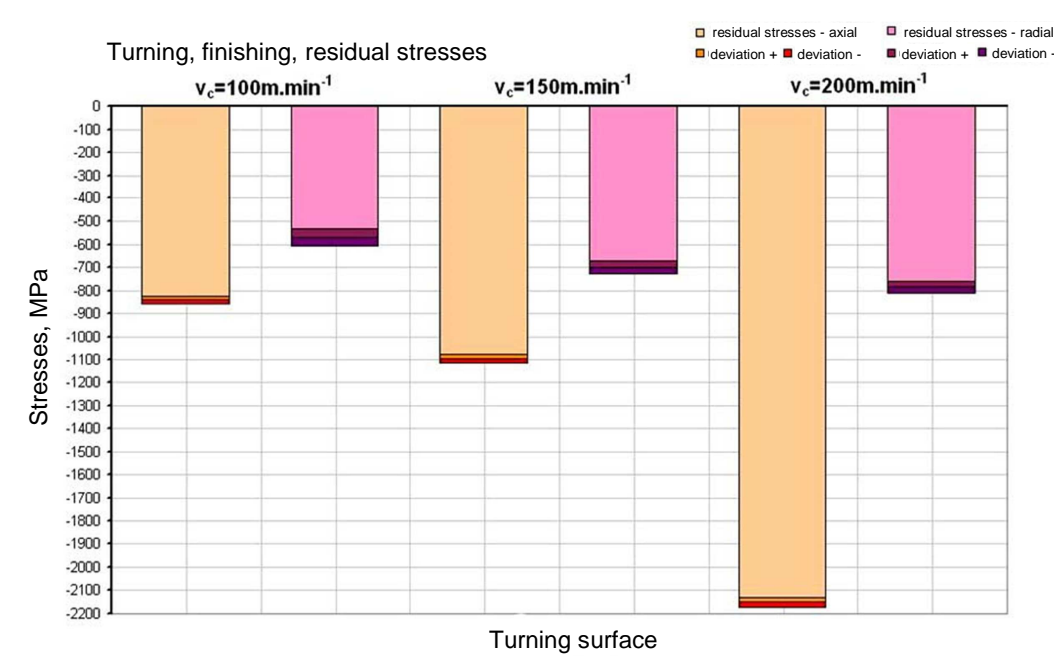

Fig. 12. Diagram of residual stresses in turning finishing

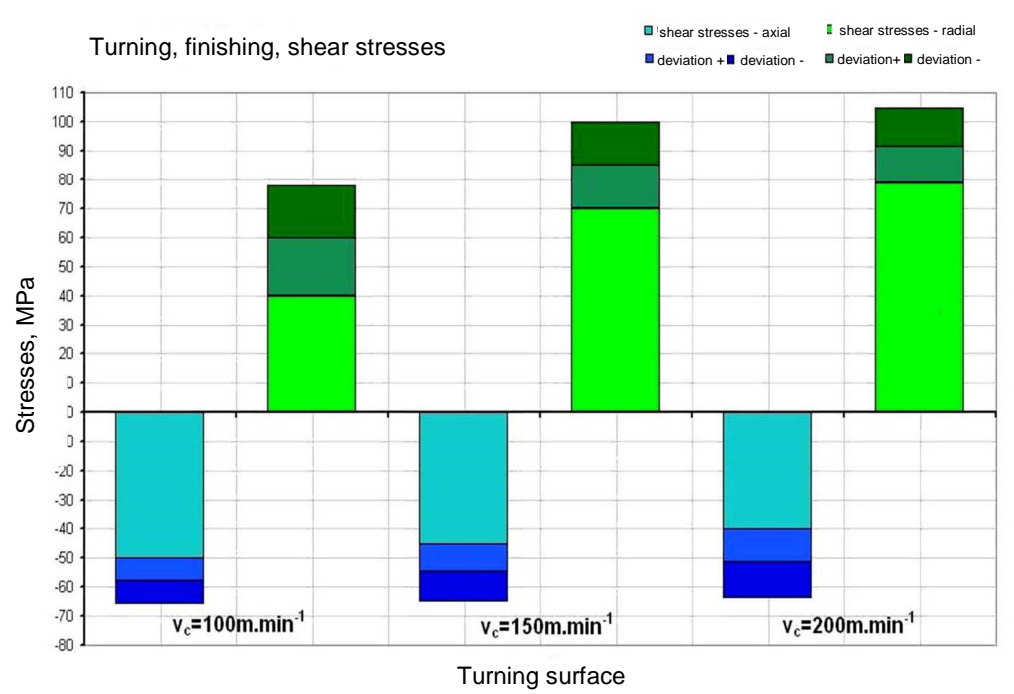

Fig. 13. Diagram of shear stresses in turning finishing

When using a cutting speed of $v_{c}=100 \mathrm{~m} \cdot \mathrm{min}^{-1}$ there were measured axial shear stresses which value was $58 \mathrm{MPa}$, radial shear stresses for the same cutting speed showed a value of $60 \mathrm{MPa}$. The value $v_{c}=150 \mathrm{~m} \cdot \mathrm{min}^{-1}$ decrease in the axial direction compared to $v_{c}=100 \mathrm{~m} \cdot \mathrm{min}^{-1}$ by $5 \%$, in the radial direction of tensile stress increased by $30 \%$. The application $v_{c}=200 \mathrm{~m} \cdot \mathrm{min}^{-1}$ decreased the value of shear stress in the axial direction compared to the values of the $v_{c}=100 \mathrm{~m} \cdot \mathrm{min}^{-1}$ by $10 \%$, in the radial direction, the tensile shear stress increased by $55 \%$ (Fig. 13). 


\section{Roughing grinding operation with a sharp wheel}

When applying a rotational speed of parts $v_{c}=38 \mathrm{~min}^{-1}$ there were measured axial residual stresses $840 \mathrm{MPa}$ and radially residual stresses $620 \mathrm{MPa}$. With increasing rotational speed, there was a reduction of residual stresses in the axial and in the radial direction. The value of $=95 \mathrm{~min}^{-1}$ reduces tension in the axial direction to $38 \mathrm{~min}^{-1}$ by $30 \%$, in the radial direction decreases by $35 \%$. When $a=255 \mathrm{~min}^{-1}$ reduces tension in the axial direction to $=38 \mathrm{~min}^{-1}$ by $40 \%$ and in the radial direction by $80 \%$ (Fig. 14).

The shear stress were measured by tensile stresses. When applying a rotational speed of parts $=38 \mathrm{~min}^{-1}$ there were measured axial shear stresses, the value was around $17 \mathrm{MPa}$, radial shear stresses applied at the same rotational speed showed a value of $10 \mathrm{MPa}$. With increasing rotational speed increased shear stress in the axial and radial direction. The value $v_{c}=95 \mathrm{~min}^{-1}$ is increased tension in the axial direction compared to $38 \mathrm{~min}^{-1}$, by $25 \%$, in the radial direction to increase the voltage by $100 \%$. When there was $a=255 \mathrm{~min}^{-1}$ tension in the axial direction increased by $52 \%$ and in the radial direction by $200 \%$ (Fig. 15).

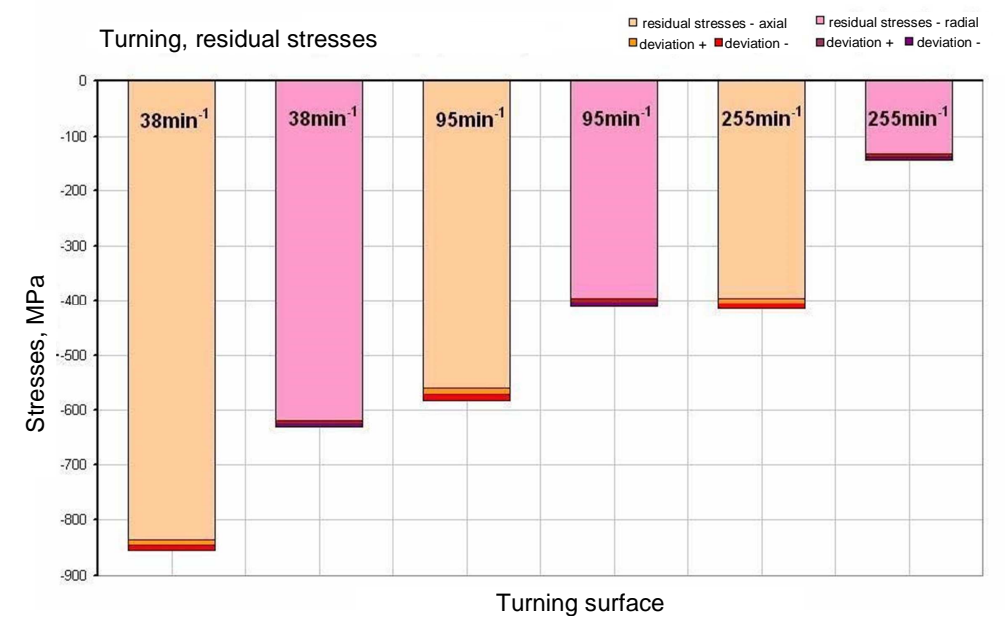

Fig. 14. Diagram of residual stresses in grinding roughing with a sharp wheel 


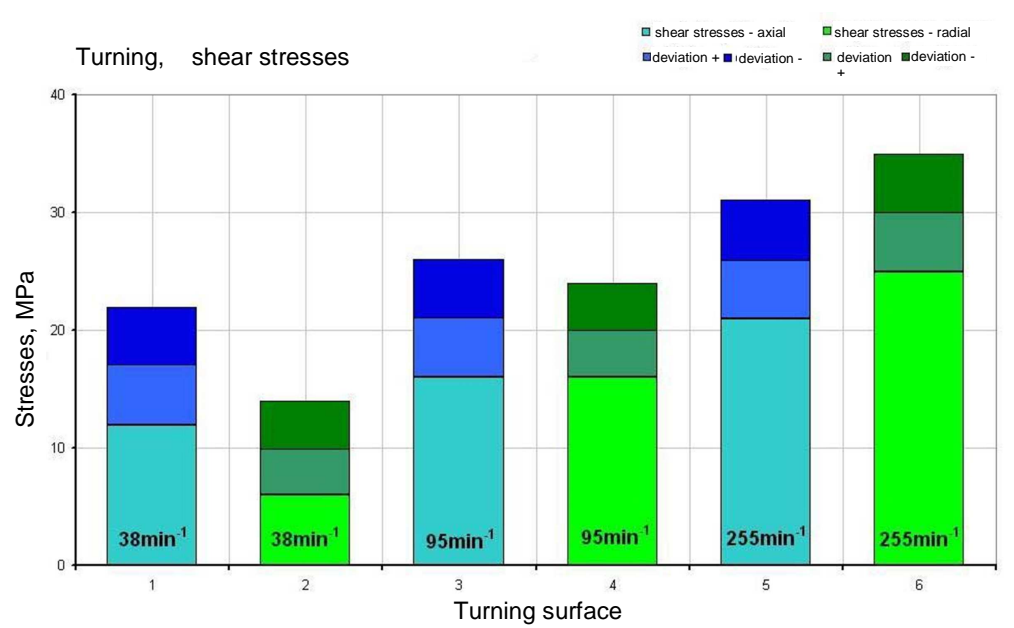

Fig. 15. Diagram of shear stresses in roughing grinding with a sharp wheel

\section{Rough grinding operation with a blunt wheel}

When applying a rotational speed $38 \mathrm{~min}^{-1}$ there were measured axial residual stress $190 \mathrm{MPa}$ tensile, stress of $120 \mathrm{MPa}$. With increasing rotational speed, there was an increase of residual stresses in the axial and radial direction, there is a change in supply pressure. The value of $95 \mathrm{~min}^{-1}$ increased the stress in the axial direction compared to the $38 \mathrm{~min}^{-1}$ by $68 \%$, in the radial direction decreased by $216 \%$ (Fig. 16).

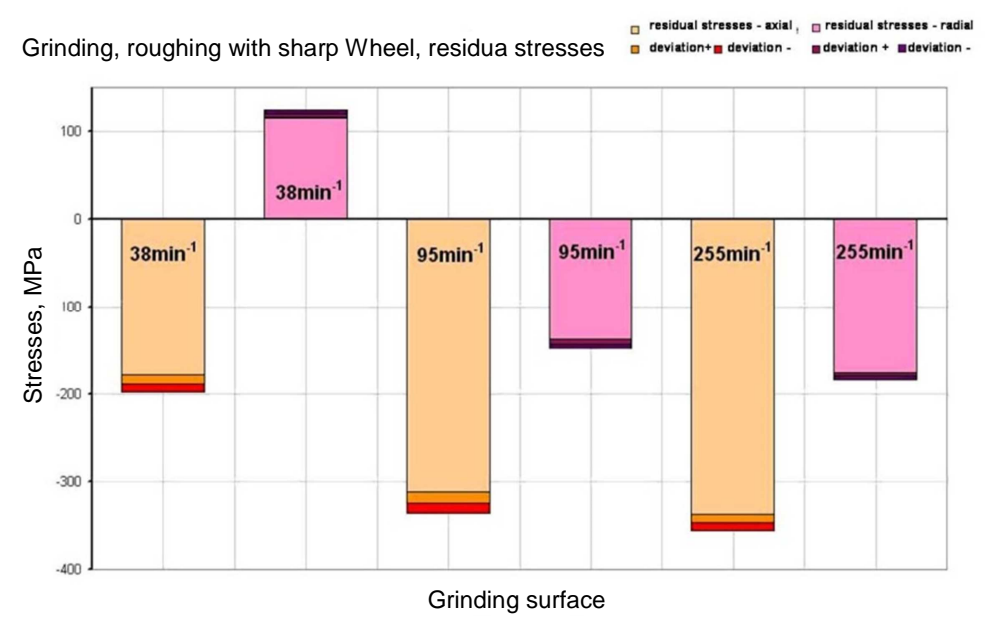

Fig. 16. Diagram of residual stresses in grinding roughing with a blunt wheel 
When using $a=255 \mathrm{~min}^{-1}$ tension in the axial direction decreased to $a=38 \mathrm{~min}^{-1}$ by $78 \%$ in the radial direction compared to the first rate decreased by $240 \%$ (Fig. 17).

The measured shear stresses were measured by tensile stresses. For a rotational speed of parts $38 \mathrm{~min}^{-1}$ there were measured axial shear stresses, the value was around $13 \mathrm{MPa}$, radial shear stresses for the same rotational speed showed the value of $9 \mathrm{MPa}$. With increasing rotational speed the shear stress in the axial and radial direction increased.

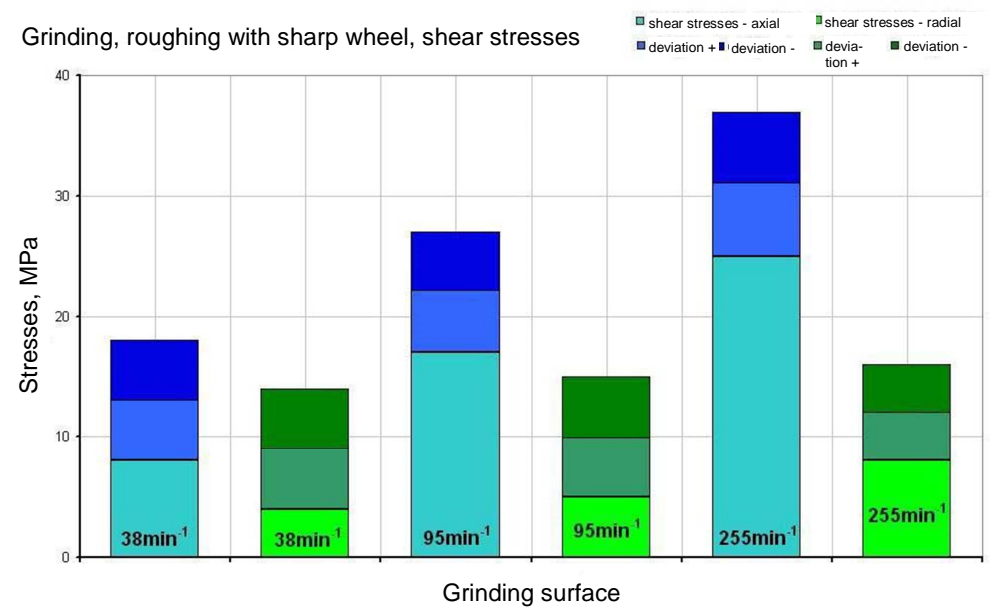

Fig. 17. Diagram of shear stresses in roughing grinding with a bunt wheel

The value $v_{c}=95 \mathrm{~min}^{-1}$ is increased in the axial direction compared to the $38 \mathrm{~min}^{-1}$ by $70 \%$. In the radial direction to increase the voltage by $11 \%$. For $a=255 \mathrm{~min}^{-1}$ there is an increased tension in the axial direction by $138 \%$ and in a radial direction by $13 \%$.

\section{Rough grinding operation with a very blunt wheel}

When applying a rotational speed of parts $38 \mathrm{~min}^{-1}$ there were measured axial residual stress values around $680 \mathrm{MPa}$ and radial residual stress showed a value of about $550 \mathrm{MPa}$. With increasing rotational speed there was a reduction of residual stress in the axial and radial direction. The value of $v_{c}=95 \mathrm{~min}^{-1}$, reduced tensions in the axial direction compared to $38 \mathrm{~min}^{-1}$ by $15 \%$, in the radial direction decreased by $4 \%$. When using $a=255 \mathrm{~min}^{-1}$ tension decreased in the axial direction to the values for the application $v_{c}=38 \mathrm{~min}^{-1}$ in the axial direction by $30 \%$ in the radial direction by $4 \%$ (Fig. 18). 


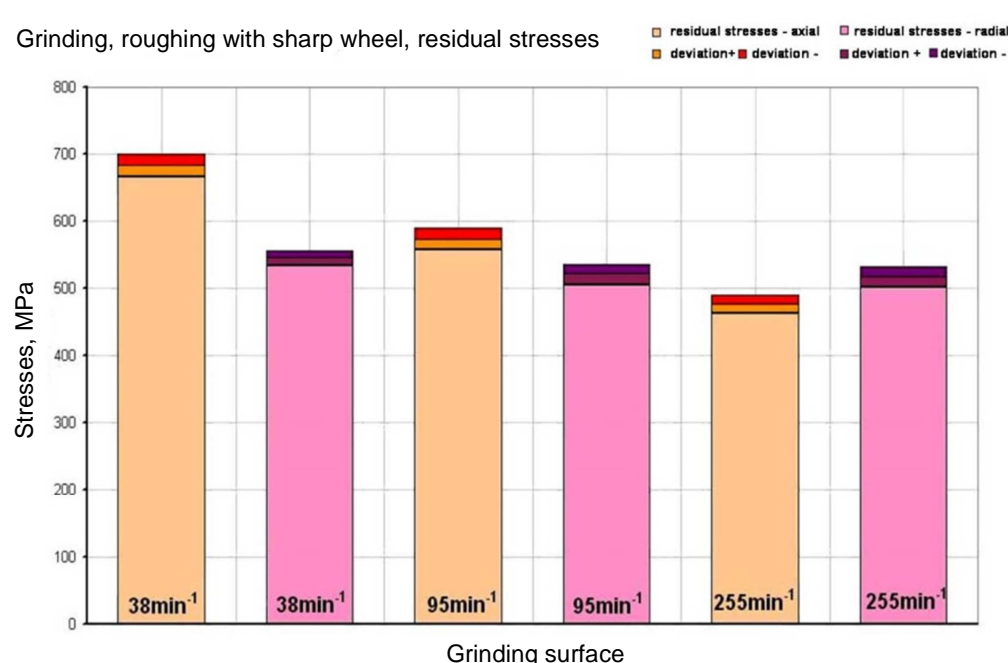

Fig. 18. Graph of residual stresses in grinding of roughing very dull blade

When applying a rotational speed of parts $=38 \mathrm{~min}^{-1}$ there were measured axial shear stresses, the value was around $20 \mathrm{MPa}$, radial shear stresses applied at the same rotational speed of components showed a value of $10 \mathrm{MPa}$. With increasing cutting speed increased shear stress in the axial and radial direction. The value of $v_{c}=95 \mathrm{~min}^{-1}$ increased tension in the axial direction compared to $38 \mathrm{~min}^{-1}$ by $10 \%$, in the radial direction voltage is increased by $280 \%$. When using $a=255 \mathrm{~min}^{-1}$ tension increased in the axial direction by $50 \%$ and the change occurred in the radial direction, where the compressive stress in the radial direction changed by $200 \%$ (Fig. 19).

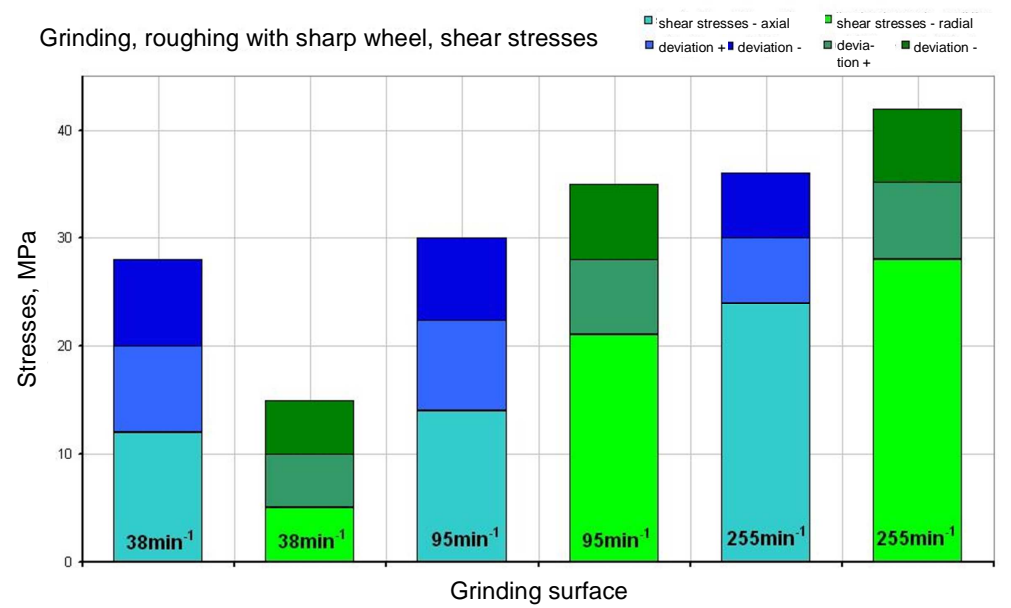

Fig. 19. Diagram of shear stresses in roughing grinding with a very blunt wheel 


\section{Grinding operation finishing}

For a rotational speed of $38 \mathrm{~min}^{-1}$ there were measured axial residual stress of about $890 \mathrm{MPa}$ and radial residual stress of approximately -580 MPa. With increasing rotational speed, in the axial residual stress in the radial direction increased. For $v_{c}=95 \mathrm{~min}^{-1}$ tension in the axial direction compared to $a=38$ $\mathrm{min}^{-1}$ in the radial direction increased by $10 \%$. When using $a=255 \mathrm{~min}^{-1}$ tension increased in the axial direction to the value of $v_{c}=38 \mathrm{~min}^{-1}$ by $20 \%$ in the radial direction and compared to the first speed increased by $15 \%$ (Fig. 20).

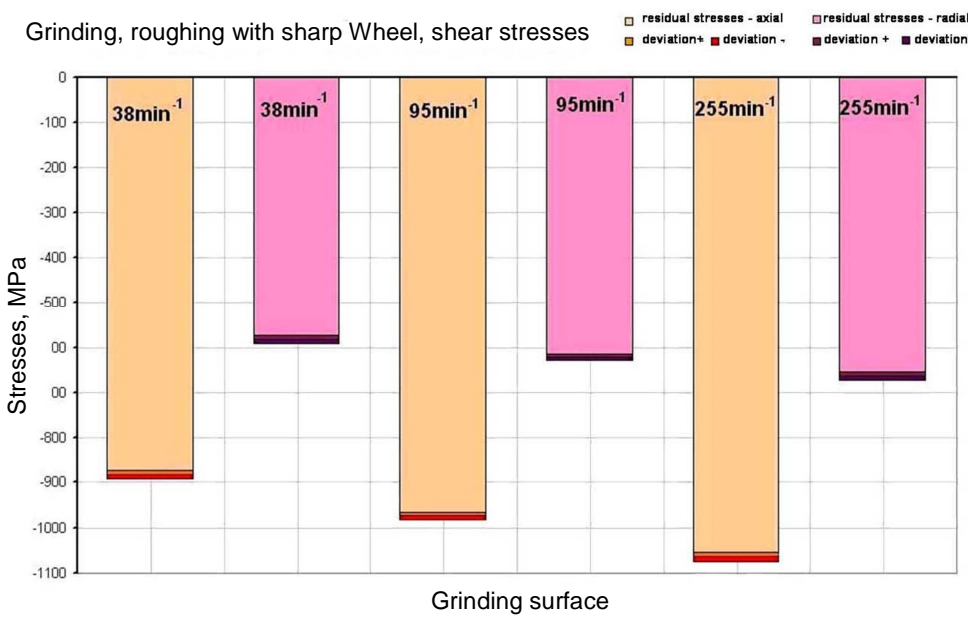

Fig. 20. Diagram of residual stresses in grinding finishing with a sharp wheel

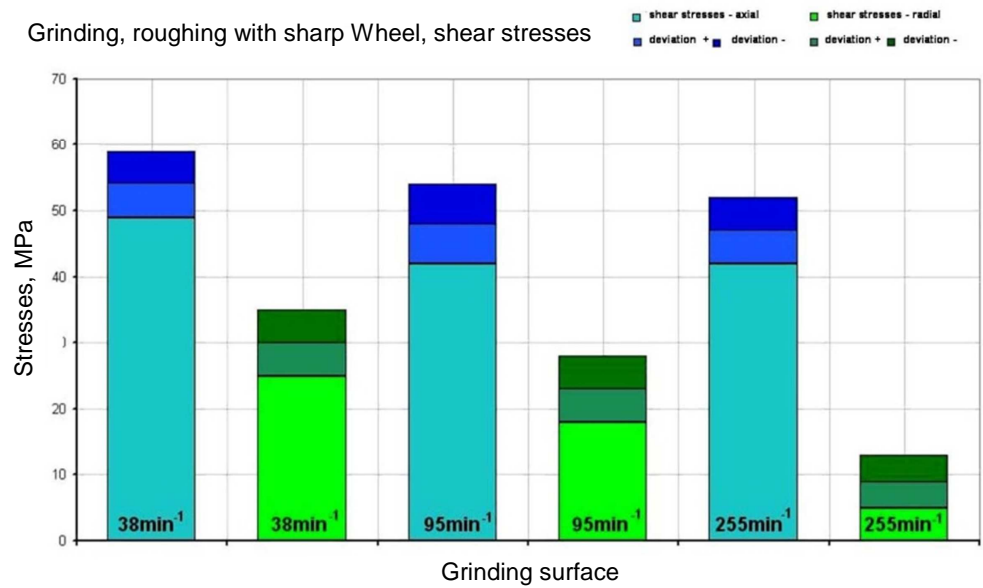

Fig. 21. Diagram of shear stresses in grinding finishing with a sharp wheel 
When measuring the shear stress only tensile stresses were measured for all the rotational speed of the workpiece. When applying a rotational speed of $38 \mathrm{~min}^{-1}$ there were measured axial shear stress, which value fluctuated around the value of $54 \mathrm{MPa}$, radial shear stresses for the same rotational speed of components showed value $30 \mathrm{MPa}$. With increasing rotational speed there was a reduction of shear stress in the axial and radial directions. The value of $v_{c}=$ $=95 \mathrm{~min}^{-1}$ reduced tension in the axial direction compared to $38 \mathrm{~min}^{-1}$ by $10 \%$, in the radial direction increased the voltage by $25 \%$. The application of $a=$ $255 \mathrm{~min}^{-1}$ reduced tension in the axial compared $a=38 \mathrm{~min}^{-1}$ direction by $15 \%$ in the radial direction, the voltage was reduced by $70 \%$ (Fig. 21).

\section{Conclusion}

After the machining process, the inner stresses appear. These stresses can be tensile or compressive. The preferred option, in all circumstances, is the compressive one. That component is used as a rolling tools which acts on the surface of a material as a ductile strength. The residual tensile strresses have a negative effect on the functional properties of a material. They have a great impact on the spread of cracks in a material. A compressive stress is appropriate because the distance between atoms are very small, they tend to associate and act against cracks in the workpiece. The value of compressive stress should not reach high values, for example $2 \mathrm{GPa}$. The optimal value of the residual stress varies is in the range of 500-700 MPa. The residual stress in a given case should not exceed $1000 \mathrm{MPa}$, the most extreme value for the steel is $2550 \mathrm{MPa}$. In this experiment, the values of residual stresses in some places were $2 \mathrm{GPa}$. Such a large residual stress was caused by previous use of the rolling mandrel. For this thorn in the process worked great forces that have a large impact on the results of measurements of residual stresses in the experiment. The grinding process was detected by measuring the residual stress that occurred in the nature of the residual tensile stress as compared with turning, where the dominant character of residual stress is compressive. For this reason, the grinding process gradually pushed out of the technological process to complete and accurate turning is replaced to prevent tensile residual stresses, reduce the economic cost of acquisition of grinding wheels and sanding their profiles, as well as to reduce the time needed for working components in the required quality. Tools with a welldefined geometry are economically more acceptable for use in the machining of complex shapes and complex components such as the use of grinding technology.

In production of the components, values of cutting tool wear, which increase the wear and tear, negatively affect the quality of the machined surface, i. e. high roughness (Fig. 22). Such negative effect is seen in places where high 
temperature is induced by machining and consequently a high voltage is generated. It is inappropriate to apply too high or too low cutting speeds when machining. The results suggest medium cutting speed to achieve optimal results in the accuracy and surface quality. The processed results suggest that turning is more favorable, because the roughness is comparable, or in some cases lower than in grinding. Turning achieved residual stress nature of the pressure to a greater extent than in grinding, where the tensile residual stress occurred more frequently.
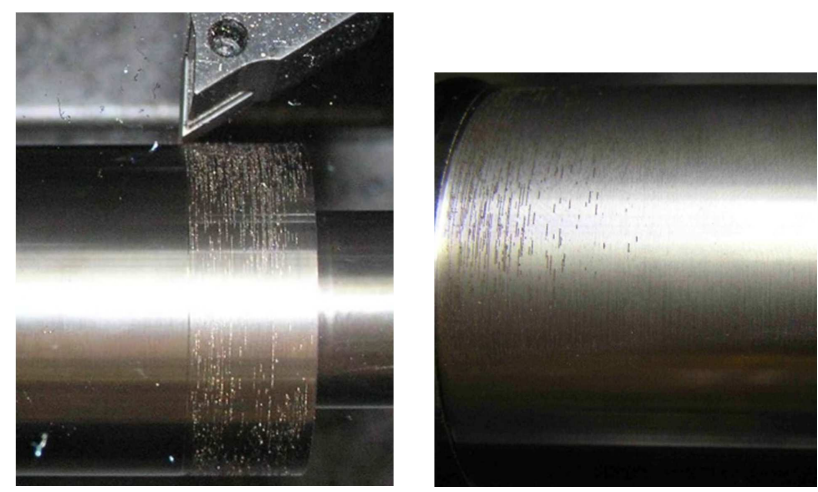

Fig. 22. Poor surface quality due to high wear of cutting plates

This work is related to the project with the University of Zilina, 2009/2.2/04-SORO OPVaV number (26220220101). His name is' Intelligent system for nondestructive evaluation technologies for functional properties of components of X-ray difractometry. Our aim is to transform the new non-destructive technologies for knowledge transfer to industry practice in the evaluation of functional properties of the surface and subsurface layers of nondestructive techniques.

\section{Reference}

[1] B. BÁTORA, K. VASILKO: Obrobené povrchy technologická dedičnost', funkčnost'. Trenčianska univerzita $\mathrm{v}$ spolupráci $\mathrm{s}$ vydavatel'stvom GC Tech, Trenčin 2000.

[2] J. BUDA, J. BÉKÉS: Teoretické základy obrábania kovov. SNTL, Bratislava 1981.

[3] A. CZÁN, D. ŠTEKLÁČ, D. STANČEKOVÁ, M. KOBOLKA, I. DANIŠ: Troubles when machining of ADI material. Strojirrenská technologie, 12(2008), 224-229.

[4] http://www.umt-old.fme.vutbr.cz 
[5] N. NÁPRSTKOVÁ, V. NÁPRSTEK, F. HOLEŠOVSKÝ: Nettings of students to the grinding process monitoring, engineering for rural development. Latvia University of Agriculture Faculty of Engineering, 2008.

[6] F. NECKÁŘR, I. KVASNIČKA: Vybrané statě z úběru material. ČVUT, Praha 1991.

[7] M. NESLUŠAN, M. ČILLIKOVÁ: Teória obrábania. Žilinská univerzita v Žiline, EDIS, Žilina 2007.

[8] M. NESLUŠAN, S. TUREK, J. BRYCHTA, R. ČEP, M. TABÁČEK: Experimentálne metódy v trieskovom obrábaní. Žilinská univerzita v Žiline, Žilina 2007.

Received in November 2012 